doi: $10.3935 /$ rsp.v26i2.1658

\section{STAVOVI STARIJIH OSOBA PREMA SMRTI I UMIRANJU}

\section{Ana Štambuk}

Zagreb: Sirius, 2018., 187 str.

Starost, starenje i smrt su teme koje nisu privlačne u svakodnevnom životu, kada su uzajamno povezane, a nisu ni pretjerano zanimljive za stručnu javnost; no, ako ih međusobno odvojimo onda su, na znanstvenom području, starost i starenje aktualnije od smrti. Naslov monografije je autorica dakle, prilično hrabro postavila, što ukazuje na njezinu posvećenost društveno zanemarenim područjima i želju za razotkrivanjem strahova od fenomena koji nagovještavaju završetak života.

Sadržaj monografije je svakako aktualan, budući da se udio starijih osoba u društvu povećava, a u vezi s tim, relativno raste i broj znanstveno obrađivanih tema koje se odnose na starost. Kada razmišljamo o stavovima prema starosti, razvijamo politike skrbi za starije osobe, svakako je važno da poznajemo što više područja koja obilježavaju živote ljudi u posljednjem životnom periodu. Važno je, također, da poznajemo i razumijemo odnos starijih ljudi prema smrti. Smrt je prilično rijetko razmatrana tema u društvenim znanostima, što je vjerojatno posljedica toga, da istraživači, akademici i stručnjaci - većina predstavnika srednje generacije - radije izbjegava ovu temu. Ana Štambuk misli drugačije. U svojoj monografiji istinski razotkriva upravo one teme koje se drugi ne usuđuju, ne žele, ili možda čak ni ne znaju kako započeti njihovo otkrivanje.

Za sve one koje prožima strah od razumijevanja starosti i smrti, malo duži uvod u monografiju lijep je poziv za razumijevanje novog područja, bez kojeg je nemoguće razumjeti smisao sadašnjeg života. Kako uopće možemo vrednovati naše življenje, postignuća, padove i uspone ako nismo svjesni da će se naš život jednom završiti? Ili, kako kaže autorica, navodeći citat Künga i Jensa (1995.) i Tobina (1999.) da su: »Smrt i umiranje pozitivno i nagrađujuće iskustvo: to može biti vrijeme osobne slobode i rasta.« (str. 14). Stari narodi nisu izbjegavali smrt, a moderni, zapadni svijet ju ignorira - no, ne može ju ignoriranjem ukloniti! Kako smo došli do takvog odnosa prema smrti, koji su nas čimbenici doveli do toga? Autorica smatra da su ključni razlozi sljedeći:

»1. Napretkom medicine, bolesne i terminalno oboljele osobe počele su primati bolju zdravstvenu skrb profesionalnih liječnika u bolnicama, nego što bi primili od članova obitelj u vlastitim domovima. Time je obitelj prestala njegovati umiruću osobu.

2. Dolaskom industrijalizacije i urbanizacije nastala je veća prostorna pokretljivost ljudi pa su se neki članovi obitelj počeli raseljavati na neka druga područja. Tako, čak ako bi bolesna osoba i ostala kod kuće, ne bi u kući više bilo dovoljno osoba potrebnih da joj pruže njegu i skrb.

3. Industrijalizacija društva stvorila je visokospecijalizirane radne uloge.

4. Nastajali su zakoni koji su regulirali brigu za umiruće osobe i pokop umrlih s ciljem da se spriječi širenje zaraznih bolesti.

5. Zbog urbanizacije, mnoge gradske obitelji više nisu imale pristup zemlji pa tako ni mjestu za pokop te su se i u tom području morale oslanjati na profesionalce.« (str. 14-15).

Unatoč racionalizaciji objašnjenja o neprihvaćanju smrti, naš život teče prema prirodnim zakonima i mi ćemo i dalje umirati. Stoga je važno da poznajemo koncept smrti i umiranja, koji autorica vrlo jasno predstavlja u prvom poglavlju kroz razumijevanje smrti u različitim religijama, filozofskim i 
sociološkim perspektivama i psihološkim teorijama. Interdisciplinarni pogled omogućuje razumijevanje smrti kao multidisciplinarnog fenomena, koji također omogućuje veći broj studija nego što ih imamo. Također omogućuje interdisciplinarnu integraciju i zajedničku skrb kako bi se promijenili negativni stavovi prema smrti i zanemarivanje ove teme u modernom društvu.

Kako bi i u znanstvenoj sferi pomaknuli zapostavljenost teme smrti, i uz nju najčešce vezane teme starosti, autorica nam se obraća u poglavlju 1.6. Upozorava, da je moguće promijeniti strah od smrti, da je važno obrazovati zaposlenike koji se brinu o umirućim, komunicirati s njima, a da prije svega moramo promijeniti vlastiti odnos prema smrti i umiranju. Pri tome, možemo učiti od starijih ljudi, jer prema mišljenju mnogih autora (npr. Marshall, Kastenbaum, Laish, Beauvoir i dr.) starije osobe se manje boje smrti i o smrti lakše razgovaraju. Važno je shvatiti da se umiranje odvija u fazama, da je to proces u kojem mi - rođaci, prijatelji, stručnjaci imamo vrijeme, nenadoknadivo!, a namijenjeno tome da ga proživimo zajedno s čovjekom koji nas napušta. Ili, kako kaže sama autorica: »Jedino u prihvaćanju neizbježnosti smrti možemo istinski prihvatiti život. Stoga je suočavanje sa smrću u starosti specifična i neizbježna tema te kao takva vrijedna istraživanja, a studij smrti zapravo je studij života jer na iskustvima starijih možemo zaključiti koje su vrijednosti zaista važne, a o njima možda premalo razmišljamo dok smo mlađi (Kuhl, 2002).« (str. 42-43).

Poglavlje 1.8. Pokret pomoći umirućima obuhvaća ključne teme koje, na području struke, mogu donijeti promjene u skrbi za umiruće. Upoznajmo se s temom palijativne skrbi i hospicijskog pokreta koji su već uzrokovali promjene na razini državnih politika. Tako autorica navodi: »Vrijedi spomenuti i preporuke povjerenstva ministara Vijeća Europe koji ističu: Vlada mora imati studiju procjene potreba za službama, za osobljem različite razine stručnosti i obrazovanjem različitih profesija, kao i dobrovoljaca.« (str. 47). Države trebaju razviti modele skrbi »koji će biti utemeljeni na kulturnom nasljeđu, ali i imati određene standarde koji će biti ujednačeni za cijelu Europsku uniju. Javno artikulirani problemi, koji su stavljeni i u političke planove, dovode do promjena u kulturnim i socijalnim pogledima na smrt i umiranje u širem kontekstu, što kao posljedicu ima konkretnu pomoć pojedincu i njegovoj obitelji.« (str. 47)

Pomoć, koja se temelji na prepoznavanju potreba umirućih, također može dati smjernice za razvoj socijalnog rada u hospicijskoj i palijativnoj skrbi. Socijalne radnice i radnici imaju ulogu u »pokretanju i stvaranju novih pristupa u životu pojedinaca, grupa i zajednice kroz zalaganje na svim razinama, kako za kvalitetu usluge - tako i za humaniji pristup u svim područjima života.« (str. 52)

Drugo i treće poglavlje odnose se na prikaz problema i hipoteza te metodologiju empirijskog istraživanja, koje je autorica provela u sklopu svoje doktorske disertacije. Na uzorku od 488 stanovnika Zagreba, različitih dobnih kategorija, provjeravala je sljedeće hipoteze:

H1: Postoje statistički značajne razlike u stavovima prema smrti i umiranju s obzirom na sociodemografske parametre, posebno na dob i spol.

H2: Postoji povezanost između kvalitete života i stavovima prema smrti i umiranju kod starijih osoba.

H3: Postoje razlike u stavovima prema smrti i umiranju s obzirom na unutarnju i vanjsku religioznost kod starijih osoba.

H4: Postoji povezanost između životnih vrijednosti i stavova prema smrti i umiranju starijih osoba.

H5: Neki stresni životni događaji (kao npr. smrt djeteta ili bračnog druga) značajno utječu na stavove prema smrti i umiranju kod starijih osoba. 
Precizno je predstavila uzorak, mjerne instrumente $\mathrm{i}$ obradu podataka.

U četvrtom poglavlju, na 85 stranica, prikazani su rezultati kao odgovori na postavljene hipoteze. Grafičkom ilustracijom rezultata i njihovom interpretacijom dobili smo detaljan uvid u nalaze, koji su prikazani u petom poglavlju, kao komentari o postavljenim hipotezama. Navodim neke od glavnih rezultata koje, također, smatramo važnima na području socijalnih politika:

- Starije osobe manje se boje smrti, više prihvaćaju smrt bijegom i više neutralno prihvaćaju smrt. Mlađe dobne skupine više izbjegavaju smrt od starijih.

- Žene više prihvaćaju smrt od muškaraca, dok muškarci više izbjegavaju smrt, posebno mlađi muškarci.

- Obrazovane osobei one koje nisu u braku, manje se boje smrti.

- Veće zadovoljstvo društvenim položajem povezano je s manjim strahom od smrti i većim prihvaćanjem smrti, a manje zadovoljstvo društvenim položajem s izbjegavanjem smrti i prihvaćanjem smrti bijegom.
- Veće zadovoljstvo obiteljskim životom i provođenjem slobodnog vremena povezano je s izbjegavanjem smrti.

Autorica sažeto predstavlja svoje nalaze u šestom poglavlju, gdje taksativno nabraja nalaze koji su specifični s obzirom na spol, dob i druge psihološke dimenzije. Zaključuje konstatacijom, koju analogno temi prihvaćanja smrti, možemo naći i u obradi drugih tabuiziranih tema. Tako »osobe, koje, inače, više prihvaćaju smrt, žele još više saznati o toj temi, za razliku od onih koje pokazuju veći strah i veće izbjegavanje.«(str. 162).

Želimo da za monografijom Ane Štambuk posegnu kako oni koje tema smrti i umiranja zanima, tako i oni koji je izbjegavaju, zato što će svima, a naročito potonjim, razotkriti razumijevanje njihovog odnosa prema ovim temama i sve pozvati da prihvate smrt kao posljednji dio života.

Izv. prof. dr. sc. Jana Mali

Fakultet za socijalni rad, Sveučilište u Ljubljani 